\title{
Drinking Water Quality: Physical and Chemical

Evaluation of Tap and Packaged Waters from Eight Local Government Areas in Lagos, Nigeria

\author{
Kafeelah Abosede Yusuf, Abdurafiu Majolagbe and Mutiu Sowemimo
}

Department of Chemistry, Faculty of

Science, Lagos State University, Nigeria

\section{Correspondence}

Kafeelah Abosede Yusuf, Department of Chemistry, Faculty of Science, Lagos State University, Nigeria

Email:kafyusuf@yahoo.co.uk

Funding information

Authors sponsor

\begin{abstract}
:
Introduction: The inadequacy of pipe borne water supplies in urban centers is a growing problem. In recent years, packaged waters became major sources of drinking water in the households and at work.

Aims: This study aimed at assessing drinking quality parameters of packaged water sold in some selected part of Lagos and compares them with the quality of tap water.

Materials and Methods: fifty seven packaged water samples from several commercial brands selected randomly and thirty tap water samples supplied by municipal pipelines were analysed for different chemical and physical parameters. Trace metals and major ions were analysed using atomic absorption spectrometry; Total hardness and chloride were measured titrimetically; $\mathrm{pH}$ and electrical conductivity were measured using a multi-purpose meter.

Results: The results showed that the concentrations of the water constituents in both tap and packaged water were below the drinking water threshold values stipulated by national and international agencies, with the exception of the nitrate $\left(\mathrm{NO}_{3}{ }^{-}\right)$content in packaged water, where $11 \%$ and $20 \%$ respectively of the bottled and sachet water samples investigated exceeded the United State Environmental Protection Agency (USEPA) standard of $10 \mathrm{mg} \mathrm{L}^{-1}$. This finding may result from a number of different reasons including substances dissolving from either natural sources or from household plumbing systems.

Conclusion: This study concludes that the systematic monitoring by drinking water authorities of water quality is essential and that a uniform system for quality control and assurance is required by the enforcement agencies (National Agency for Foods and Drugs Administration and Control and the Ministry of Health) in the 'packaged water' industry.

Keywords: Packaged water; Drinking water quality; Tap water
\end{abstract}

All co-authors agreed to have their names listed as authors.

This is an open access article under the terms of the Creative Commons Attribution License, which permits use, distribution and reproduction in any medium, provided the original work is properly cited.

(C) 2018 The Authors. Journal of Research and Reviews in Science-JRRS, A Publication of Lagos State University 


\section{INTRODUCTION}

The unwholesomeness of drinking water resulting from contaminants released from different anthropogenic sources has become a global concern $[1,2]$. Over at least the past two decades, there has been increased concern regarding the quality of tap water due to pollution and its undesirable taste and odor $[3,4,5]$. The pollution of tap water could originate from several sources, including contamination from water pipes and storage tanks $[3,6]$, and in the absence of proper and periodic maintenance, from disinfectant by-products resulting from the treatment of water by ozonation and chlorination [3,7]. Thus, for the sake of safety and quality, people are switching from tap water to bottled water.

The Lagos Water Supply System comprising three (3) major waterworks (Adiyan, lju and Isashi), twentyseven (27) mini-waterworks and ten (10) microwaterworks with a combined production capacity of 240 million gallons per day (MGD) meets about $40 \%$ current demand and derive their water resources in the form surface water and groundwater [8]. Rapid population growth, coupled with accelerated industrialization and urbanization, corruption, climate change, unreliable electricity and seeming mismanagement of resources have hampered the capacity of government owned municipal water providers to meet the needs of the Lagos populace. The inadequate and lack of accessible drinking water have prompted the consume of packaged waters, thereby consumers rely upon their senses with packaged waters being perceived as pure, safe and of good taste, thus, their consumption is increasing despite the excessively high prices compared to tap water $[9,10]$.

Packaged waters (PW) are drinking water packed in plastic bottles and for the low and middle income population, the packed water is also available in the form of relatively cheaper, machine sealed sachets and may be sold in shops, on the street, or delivered to homes. The volumes of sachet water (SW) consumed are often substantial relative to total daily drinking water consumption: a study of $137 \mathrm{PW}$ users in Ibadan, Nigeria found that $58 \%$ consumed between two and four $50 \mathrm{cl}$ sachets per day, while $28 \%$ consumed more than four sachets per day $[11,12]$. Bottled water (BW) are drinking water sealed in polyethylene terephthalate (PET) bottles and either drawn from natural springs, or deep boreholes and treated according to the specifications by passing through various filters and disinfected appropriately. They are available in $50 \mathrm{cl}, 75 \mathrm{cl}$, and $150 \mathrm{cl}$ bottles. These are relatively expensive (at the rate of Naira 50 to 150) and very popular among hotels and restaurants and people from higher socioeconomic strata. Sachet water (SW) are drinking water sealed in polyethylene pouches popularly called "pure water" which is manufactured by small scale industries with a registered name and supposed to have been prepared under Government stipulated hygienic quality regulations. According to the specifications, the water is passed through a series of activated charcoal or suitable filtering media and Millipore or equivalent filters of a specific pore size, and disinfected under ultraviolet radiation for a specific period. They are packed in $50 \mathrm{cl}$ nylon / plastic film sachets, put in larger sacks in dozens and transported to various distribution points in open pick-up vehicles. The price is affordable (Naira 10) mostly for the low and middle income groups. They are popular at social gatherings and public places.

While a lot of studies have been done to assess the physicochemical quality of PW, relatively fewer studies have compared the physicochemical quality of PW to tap water [11]. Due to public concern about the perceived risks of tap water and the perceived safety packaged water, this study aims to (1) evaluate whether the quality of tap water in Lagos meets international standards for drinking water, (2) to examine the drinking quality parameters of packaged water sold on the Lagos metropolis, (3) compare the quality of the packaged waters with that of tap water. The results may be useful for improving the current legislation on packaged waters, and also to guide the consumers in the choice of different packaged water types.

\section{MATERIAL AND METHODS}

\subsection{STUDY AREA}

The study area is made up of eight local government areas. Lagos city lies on the longitude $3^{\circ} 23^{\prime}$ East of Greenwich meridian and latitude $6^{\circ} 27^{\prime}$ North of the Equator. Besides being the former capital of Nigeria, it is one of the fastest growing megacities and also one of the most populous urban agglomerations in the world. The city has a tropical climate with an average relative humidity of $79 \%$. Mean monthly temperature ranges from $23^{\circ} \mathrm{C}-32^{\circ} \mathrm{C}$. Being located in a coastal area and influenced by strong sea-based disturbances, Lagos experiences an average wind speed of $4.3 \mathrm{~km} /$ h. However, the city is characterized by low level of environmental sanitation, poor housing, and lack of potable water and improper management of wastes.

\subsubsection{Sampling of waters}

For the packaged water analysis, 27 bottled water and 30 sachet water samples were purchased between the months of October and December 2015 from water vendors in the markets, food serving areas (Bukhas) and motor parks in eight Local Government Areas (Somolu, Ikeja, Surulere, Ojo, Yaba, Oshodi / Isolo, Alimosho and Mushin) of the Lagos metropolis as shown in Fig. 1. For the tap water analysis, 30 tap waters were collected from same Local Government Areas (LGAs). The samples were stored in a cool box and carried to the laboratory. The samples collected were immediately processed for physico-chemical analysis as described in Standard Methods [13]. 


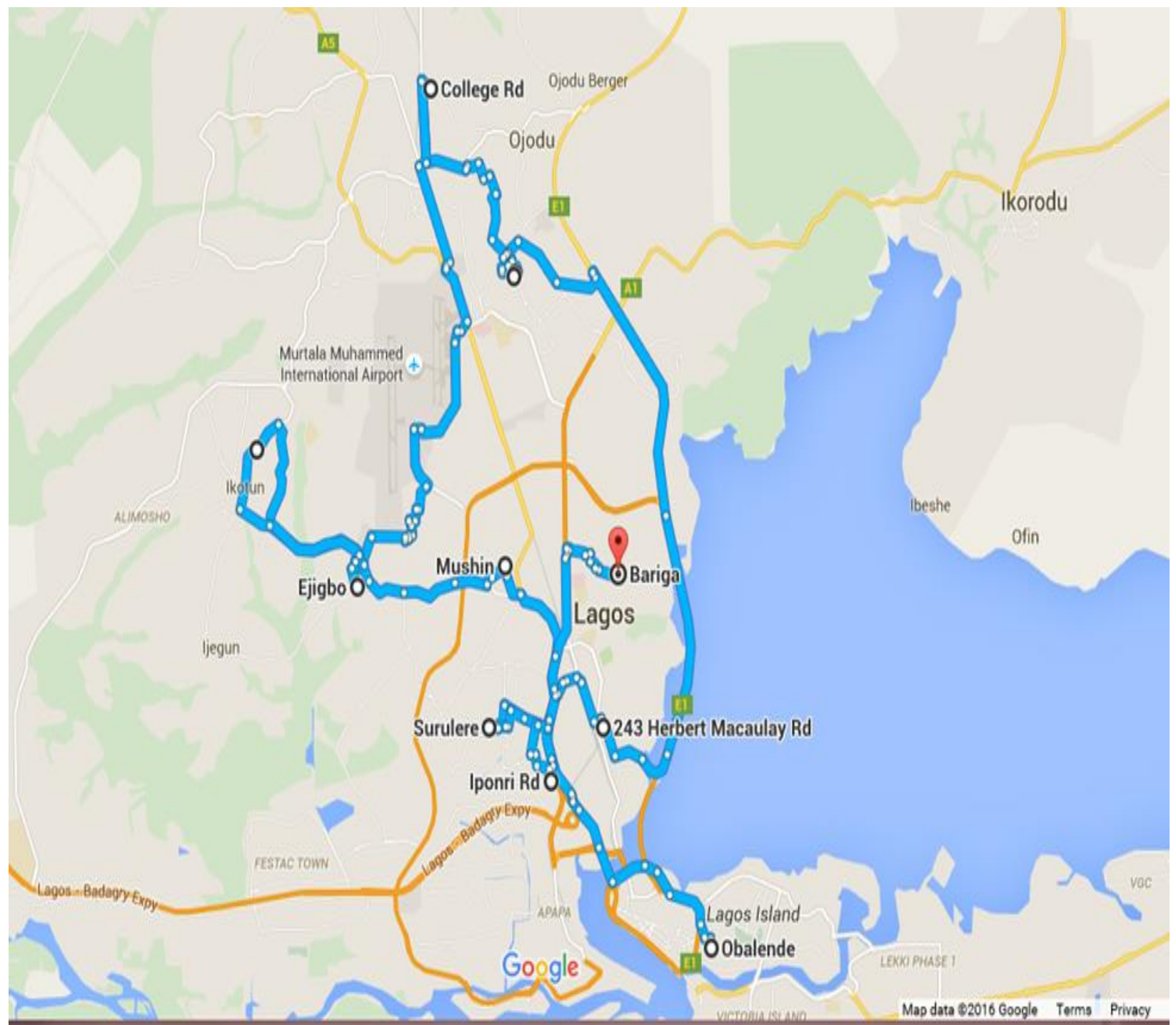

- Fig. 1. Map showing the location of bottled, sachet and tap water samples considered in this study. 


\subsubsection{Physico-chemical Analysis}

The electrical conductivity (EC) and $\mathrm{pH}$ were determined in situ using Jenway 470 Conductivity meter and Jenway $3505 \mathrm{pH}$ meter respectively. Total hardness was determined by EDTA titration method using Eriochrome Blak T as indicator. Chloride was determined Mohr's method using potassium chromate as indicator. Nitrate and Sulphate were detemined using $\mathrm{HACH}$ DR-3900 spectrophotometer and chemical reagents supplied along with the kit were used for analyses. The determination of metals in drinking water samples were performed with a Solar Thermo Electron Corporation AA Series Spectrometer. All analyses were carried out in accordance with standard methods for the examination of water and wastewater [13].

All the plastics and glassware were washed and soaked with $5 \%$ nitric acid $\left(\mathrm{HNO}_{3}\right)$ for 24 hours and rinsed thoroughly with distilled water. The water samples were labeled acidified and non-acidified subsamples. The non-acidified sample was used to analyse all parameters with the exception of metals. For acidified samples, $5 \% \mathrm{HNO}_{3}$ was added to maintain $\mathrm{pH}$ 2. The samples were preserved at $4^{\circ} \mathrm{C}$ before analysis. Quality control and Quality Assurance were ascertained appropriately.

\subsection{Statistical Analysis}

\subsubsection{Correlation Analysis (CA)}

In the present study, "Pearson $r$ correlation" was used to evaluate the linear relationships between various pairs of variables, with statistical significance set at $p<0.01$ and $p<0.05$. The value of correlation coefficient ranges between -1.0 and +1.0 . The earlier value $(-1.0)$ represents a perfect inverse relationship between the two variables, whereas the later one $(+1.0)$ occurs when the two variables react in exactly the same way as their values change. A correlation coefficient of zero suggests that the two variables are independent of each other.

\subsubsection{Principal Components Analysis (PCA)}

PCA is used to reduce a large number of variable parameters (identified in water samples) to a small number of principal components [14-19]. Varimax normalized rotation was applied to the principal components in order to reduce the contribution of significantly minor variables. The number of PCs extracted (to explain the underlying data structure) is defined by using the "Kaiser criterion" [20] leaving for consideration only factors with eigenvalues greater than one.

\subsubsection{Hierarchical Cluster Analysis (HCA)}

The HCA $[15,17,19,21]$ was used to determine if the drinking water samples can be grouped into statistically distinct groups (clusters). These water types were classified according to their major ion composition, for which the Ward's method was used as amalgamation rule to obtain the hierarchical associations. Classification results of the HCA are generally presented in a graphical form called "dendogram". The statistical analyses of data were performed using SPSS 16.0.

\subsubsection{Linear Discriminant Analysis (LDA)}

LDA was used to achieve maximum discrimination among known groups. Groups are forced to be as statistically different as possible by forming a weighted linear combination of the discriminating variables (i.e. the ion concentrations and the $\mathrm{pH}$ ), the weights or canonical discriminant function coefficients $(\beta \mathrm{i})$ are estimated so that they result in an optimal separation between the groups. Also, LDA provided better insight into the relationship between group membership and the variables used to predict group membership $[22,23]$. The Wilk's Lambda was used to catch the importance of the discriminating function. The Wilk's Lambda is an inverse measure of the functions discriminating power; the smaller the value of Wilk's Lambda the better the discriminating power of the function [16].

\section{RESULTS AND DISCUSSION}

The physical and chemical composition $(\mathrm{pH}, \mathrm{EC}, \mathrm{TH}$, $\mathrm{Na}, \mathrm{K}, \mathrm{Cl}^{-}, \mathrm{NO}_{3}{ }^{-}, \mathrm{SO}_{4}{ }^{2-}$ ) in packaged and tap waters were reported in Tables I - III together with recommended values established by regulatory bodies [24-26] for drinking water. The $\mathrm{pH}$ values ranged between 5.10 and 6.85 indicating slightly acidic nature. Recommended $\mathrm{pH}$ values for drinking water according to local and international standards should be 6.5 to 8.5. Based on Total Hardness [27] classification, $86 \%$ of the water samples were classified as soft while 14 $\%$ were considered moderately soft.

Nitrate concentrations in the packaged and tap water samples were below the Nigerian and $\mathrm{WHO}$ recommended value for drinking water (i.e. $50 \mathrm{mg} \mathrm{L}^{-1}$ for short-term exposure). The primary health concern regarding nitrate is the formation of methemoglobinemia, so-called 'blue-baby syndrome': nitrate is reduced to nitrite in the stomach of infants, and nitrite is able to oxidize hemoglobin to methemoglobin, which is unable to transport oxygen around the body [9]. USEPA has set the primary drinking water standard (from public water supplies) for nitrate at $10 \mathrm{mg} \mathrm{L}^{-1}$. Some packaged water samples considered in this study showed $\mathrm{NO}_{3}$ - concentrations higher than USEPA guidelines of $10 \mathrm{mgL}-1$. [Tables I and II]. Concentrations of $\mathrm{NO}_{3}{ }^{-} \geq 10 \mathrm{mg} \mathrm{L}^{-1}$ occur in 11 $\%$ and $20 \%$ of bottled and sachet water samples, respectively. 
Table I: Physico-chemical characteristics of Packaged (Bottled Water) water and the standard limits recommended by Nigerian and international regulations for drinking water

\begin{tabular}{lcccccc}
\hline $\begin{array}{l}\text { Parameters } \\
\text { Sample }\end{array}$ & $\mathrm{pH}$ & $\begin{array}{c}\mathrm{EC} \\
(\mathrm{mS} / \mathrm{cm})\end{array}$ & $\begin{array}{c}\mathrm{TH} \\
(\mathrm{mg} / \mathrm{L})\end{array}$ & $\begin{array}{c}\mathrm{Cl}^{-} \\
(\mathrm{mg} / \mathrm{L})\end{array}$ & $\begin{array}{c}\mathrm{NO}^{3}{ }^{-} \\
(\mathrm{mg} / \mathrm{L})\end{array}$ & $\begin{array}{c}\mathrm{SO}_{4}{ }^{2-} \\
(\mathrm{mg} / \mathrm{L})\end{array}$ \\
\hline BW1 & 6.20 & 0.17 & 60.00 & 27.00 & 6.80 & 3.67 \\
BW2 & 5.90 & 1.00 & 31.50 & 24.00 & 21.35 & 8.05 \\
BW3 & 5.43 & 0.34 & 16.00 & 15.00 & 6.40 & 2.33 \\
BW4 & 5.67 & 0.27 & 13.33 & 9.00 & 9.43 & 2.67 \\
BW5 & 5.33 & 0.56 & 32.00 & 19.67 & 9.40 & 7.37 \\
BW6 & 5.97 & 0.16 & 13.33 & 15.00 & 5.60 & 10.67 \\
BW7 & 6.17 & 0.14 & na & 13.00 & 5.27 & 2.17 \\
BW8 & 6.41 & 0.09 & na & 4.67 & 3.27 & 5.33 \\
BW9 & 6.70 & 0.30 & na & 20.67 & 7.67 & 9.00 \\
WHO, & $6.5-8.5$ & & 500.00 & 250.00 & 50.00 & 500.00 \\
2011 & & & & & & \\
NSDWQ, & $6.5-8.5$ & & 150.00 & 250.00 & 50.00 & 100.00 \\
2007 & & & & & & \\
USEPA, & $6.5-8.5$ & & & & & \\
2011 & & & & & & \\
\hline
\end{tabular}

na = not available; NSDWQ: Nigerian Standards for Drinking Water Quality [24]; WHO: World Health Organization for Drinking Water [26]; USEPA: United State Environmental Protection Agency [25]

Table II: Physico-chemical characteristics of packaged (Sachet Water) water and the standard limits recommended by Nigerian and international regulations for drinking water

\begin{tabular}{|c|c|c|c|c|c|c|}
\hline $\begin{array}{l}\text { Parameters } \\
\text { Sample }\end{array}$ & $\mathrm{pH}$ & $\begin{array}{l}\mathrm{EC} \\
\mathrm{mS} / \mathrm{cm}\end{array}$ & $\begin{array}{l}\mathrm{TH} \\
\mathrm{mg} / \mathrm{L}\end{array}$ & $\begin{array}{l}\mathrm{Cl}^{-} \\
\mathrm{mg} / \mathrm{L}\end{array}$ & $\begin{array}{l}\mathrm{NO}_{3}^{-} \\
\mathrm{mg} / \mathrm{L}\end{array}$ & $\begin{array}{l}\mathrm{SO}_{4}{ }^{2-} \\
\mathrm{mg} / \mathrm{L}\end{array}$ \\
\hline SW1 & 6.60 & 0.08 & 13.00 & 6.00 & 6.17 & 8.37 \\
\hline sw2 & 6.37 & 0.27 & 44.00 & 10.00 & 3.50 & 8.33 \\
\hline sw3 & 6.60 & 0.55 & 49.00 & 14.00 & 10.75 & 8.33 \\
\hline SW4 & 6.40 & 0.15 & 0.00 & 11.00 & 3.47 & 3.67 \\
\hline SW5 & 6.53 & 0.23 & 12.67 & 10.00 & 9.07 & 1.67 \\
\hline SW6 & 6.67 & 0.90 & 32.00 & 21.33 & 24.13 & 3.33 \\
\hline SW7 & 5.93 & 0.20 & 4.00 & 11.33 & 6.03 & 9.67 \\
\hline SW8 & 6.47 & 0.20 & 14.00 & 11.67 & 7.23 & 11.00 \\
\hline SW9 & 6.27 & 0.10 & 18.00 & 11.00 & 4.60 & 7.67 \\
\hline SW10 & 6.40 & 0.57 & 16.67 & 11.67 & 5.73 & 7.33 \\
\hline $\begin{array}{l}\text { WHO, } \\
2011\end{array}$ & $6.5-8.5$ & & 500.00 & 250.00 & 50.00 & 500.00 \\
\hline $\begin{array}{l}\text { NSDWQ, } \\
2007\end{array}$ & $6.5-8.5$ & & 150.00 & 250.00 & 50.00 & 100.00 \\
\hline $\begin{array}{l}\text { USEPA, } \\
2011\end{array}$ & $6.5-8.5$ & & & 250.00 & 10.00 & 250.00 \\
\hline
\end{tabular}

na = not available; NSDWQ: Nigerian Standards for Drinking Water Quality [24]; WHO: World Health

Organization for Drinking Water [26]; USEPA: United State Environmental Protection Agency [25] 
Table III: Physico-chemical characteristics of tap (TW) water and the standard limits recommended by Nigerian and international regulations for drinking water.

\begin{tabular}{|c|c|c|c|c|c|c|}
\hline $\begin{array}{l}\text { Parameters } \\
\text { Sample }\end{array}$ & $\mathrm{pH}$ & $\begin{array}{l}\mathrm{EC} \\
\mathrm{mScm}\end{array}$ & $\begin{array}{l}\mathrm{TH} \\
\mathrm{mg} / \mathrm{L}\end{array}$ & $\begin{array}{l}\mathrm{Cl}^{-} \\
\mathrm{mg} / \mathrm{L}\end{array}$ & $\begin{array}{l}\mathrm{NO}_{3}^{-} \\
\mathrm{mg} / \mathrm{L}\end{array}$ & $\begin{array}{l}\mathrm{SO}_{4}{ }^{2-} \\
\mathrm{mg} / \mathrm{L}\end{array}$ \\
\hline TW1 & 5.65 & 0.32 & 42.00 & 11.00 & 3.60 & 25.00 \\
\hline TW2 & 5.10 & 0.29 & 10.90 & 23.00 & 9.50 & 3.00 \\
\hline TW3 & 5.80 & 1.70 & 35.00 & 7.50 & 2.27 & 4.90 \\
\hline TW4 & 6.30 & 5.80 & 50.00 & 9.00 & 1.70 & 14.00 \\
\hline TW5 & 5.90 & 1.21 & 32.00 & 7.00 & 3.60 & 7.00 \\
\hline TW6 & 6.20 & 0.37 & 52.00 & 8.00 & 2.40 & na \\
\hline TW7 & 6.15 & 0.25 & 48.00 & 5.00 & 1.45 & na \\
\hline TW8 & 6.05 & 0.28 & na & 11.00 & 3.50 & na \\
\hline TW9 & 6.25 & 0.47 & na & 11.00 & 3.50 & na \\
\hline TW10 & 6.85 & 0.62 & 50.00 & 1.00 & 3.20 & na \\
\hline $\begin{array}{l}\text { WHO, } \\
2011\end{array}$ & \multicolumn{2}{|l|}{$6.5-8.5$} & 500.00 & 250.00 & 50.00 & 500.00 \\
\hline NSDWQ & \multicolumn{2}{|l|}{$6.5-8.5$} & 150.00 & 250.00 & 50.00 & 100.00 \\
\hline 2007 & & & & & & \\
\hline $\begin{array}{l}\text { USEPA, } \\
2011\end{array}$ & \multicolumn{3}{|l|}{$6.5-8.5$} & 250.00 & 10.00 & 250.00 \\
\hline
\end{tabular}

na = not available; NSDWQ: Nigerian Standards for Drinking Water Quality [24]; WHO: World Health Organization for Drinking Water [26]; USEPA: United State Environmental Protection Agency [25]

The trace metals $(\mathrm{Zn}, \mathrm{Mn}, \mathrm{Fe}, \mathrm{Ni}, \mathrm{Cd}$ and $\mathrm{Pb})$ in packaged waters were found at median and maximum concentrations significantly higher than the corresponding median and maximum concentrations in tap waters (Figs. Ila-llh),

(lla)

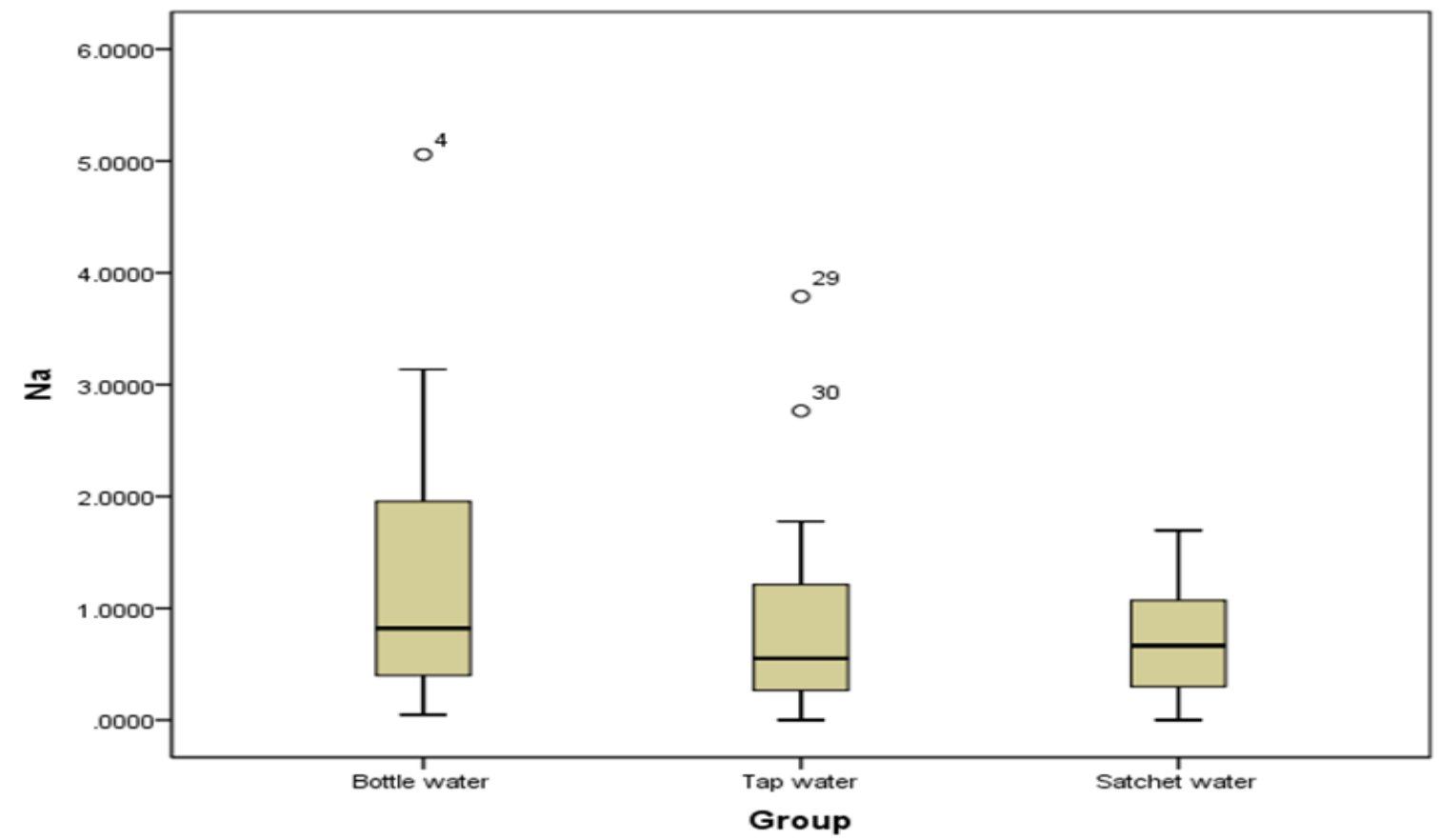

Fig lla: Box-plot showing Na concentrations in packaged (Bottled and Sachet) and tap water samples. Each box includes the 25th and 75th percentiles with the median as thick line; bottom and upper whiskers respectively show the smallest and largest values and the circles indicate the extreme values (outliers) 
(llb)

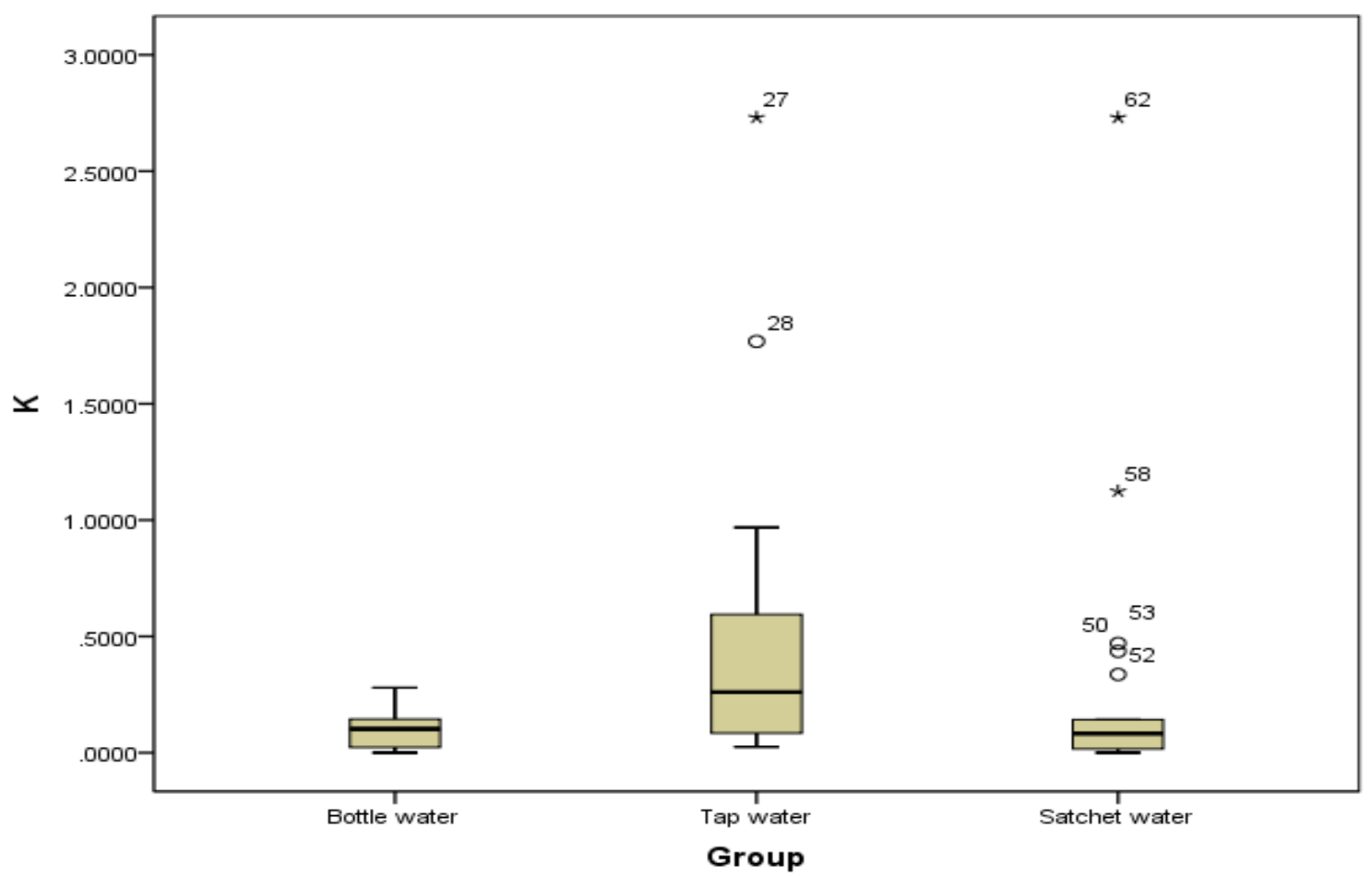

Fig Illb: Box-plot showing $\mathrm{K}$ concentrations in packaged (Bottled and Sachet) and tap water samples. Each box includes the 25th and 75th percentiles with the median as thick line; bottom and upper whiskers respectively show the smallest and largest values and the circles indicate the extreme values (outliers)

IIC

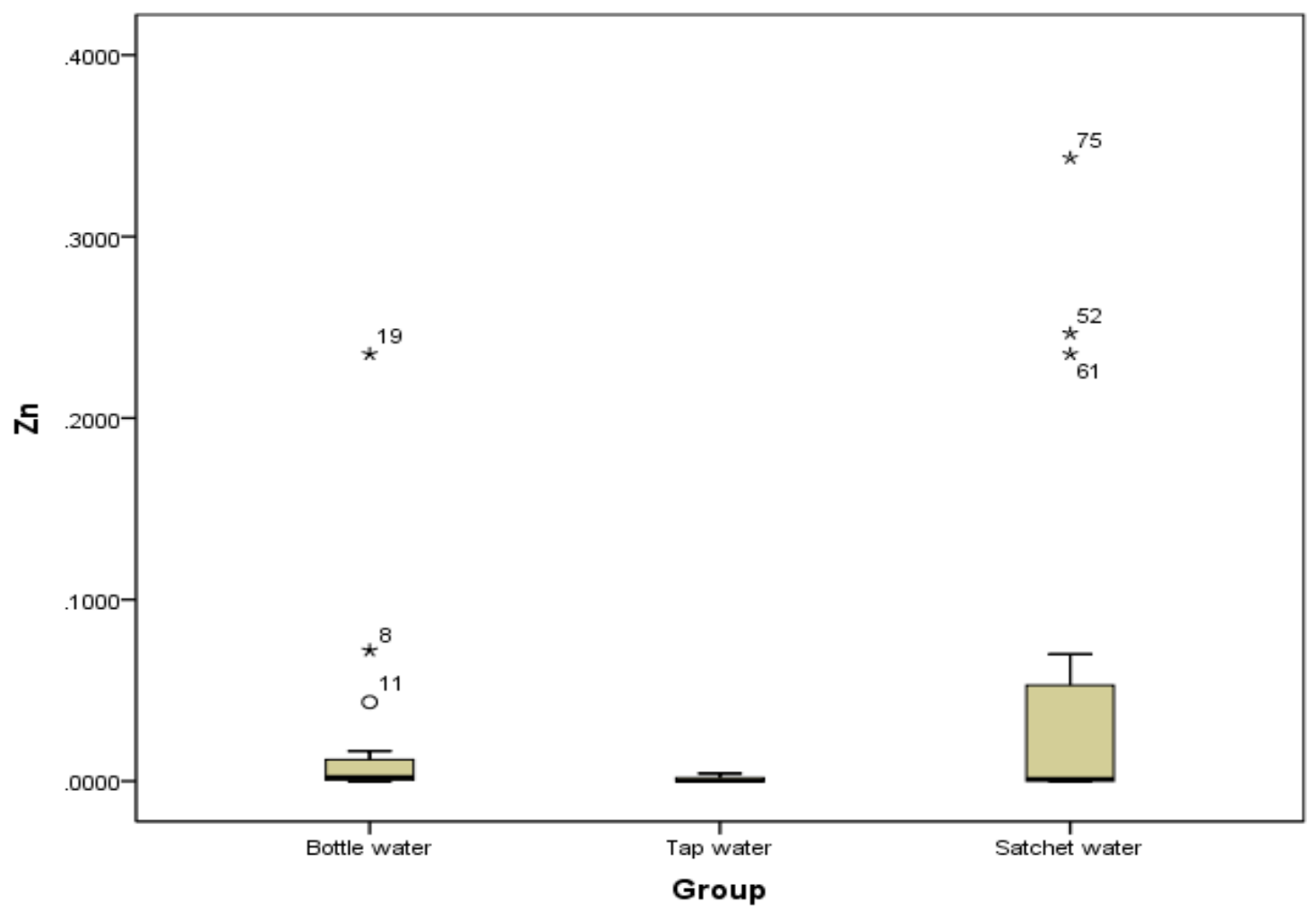

Fig Ilc: Box-plot showing Zn concentrations in packaged (Bottled and Sachet) and tap water samples. Each box includes the 25th and 75th percentiles with the median as thick line; bottom and upper whiskers respectively show the smallest and largest values and the circles indicate the extreme values (outliers) 
(IId)

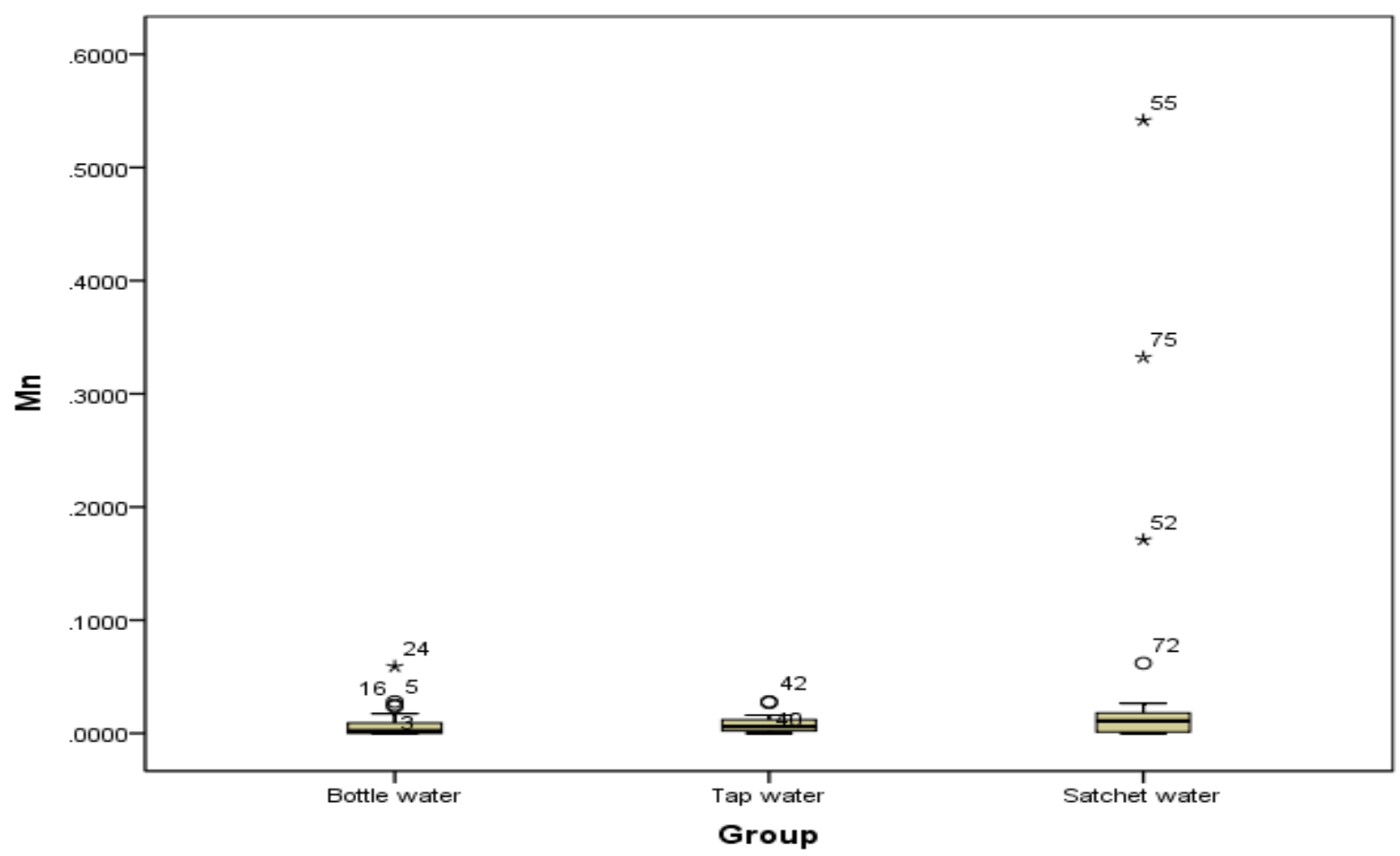

Fig Ild: Box-plot showing Mn concentrations in packaged (Bottled and Sachet) and tap water samples. Each box includes the 25th and 75th percentiles with the median as thick line; bottom and upper whiskers respectively show the smallest and largest values and the circles indicate the extreme values (outliers)

(lle)

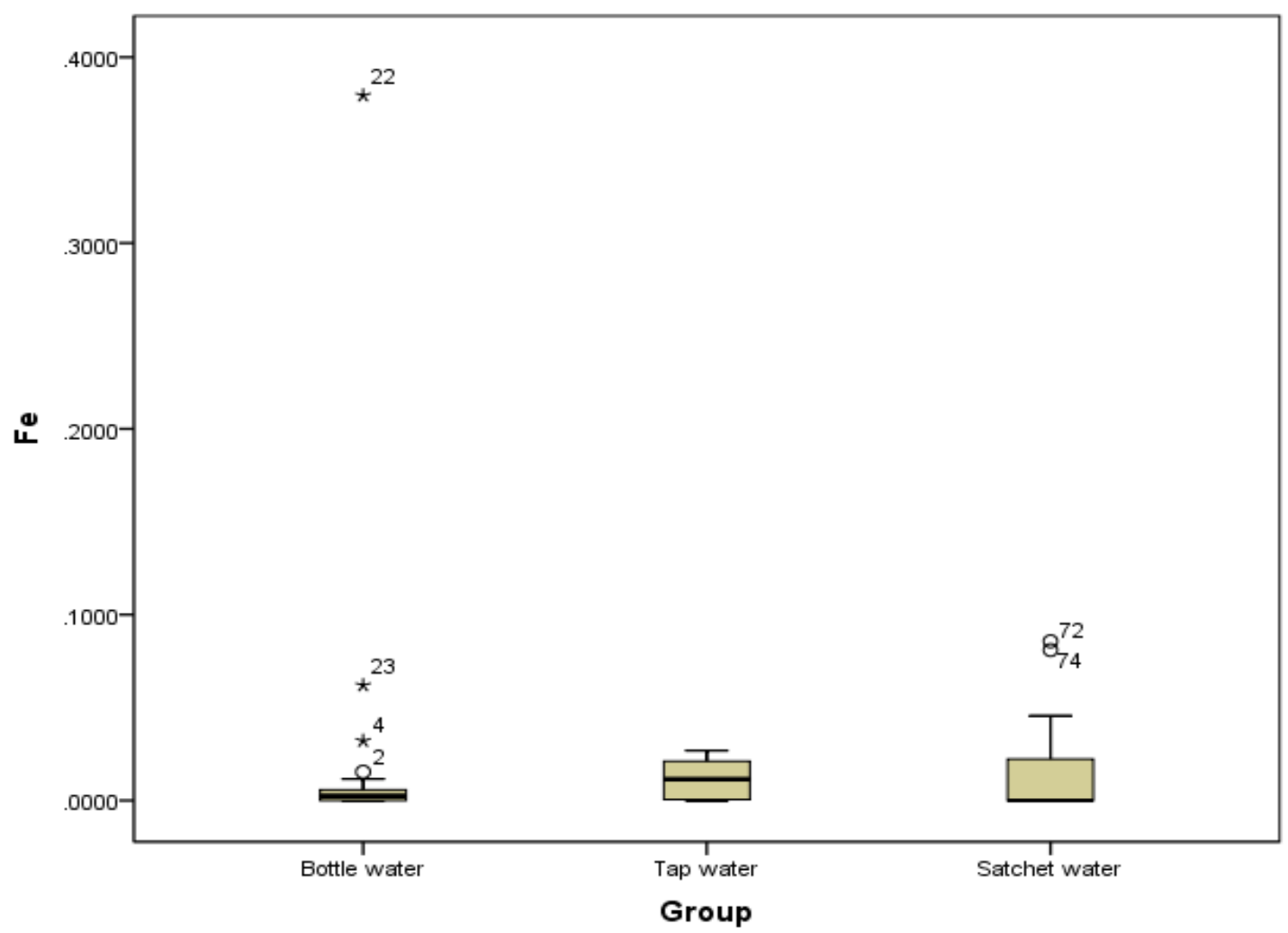

Fig lle: Box-plot showing Fe concentrations in packaged (Bottled and Sachet) and tap water samples. Each box includes the 25th and 75th percentiles with the median as thick line; bottom and upper whiskers respectively show the smallest and largest values and the circles indicate the extreme values (outliers) 


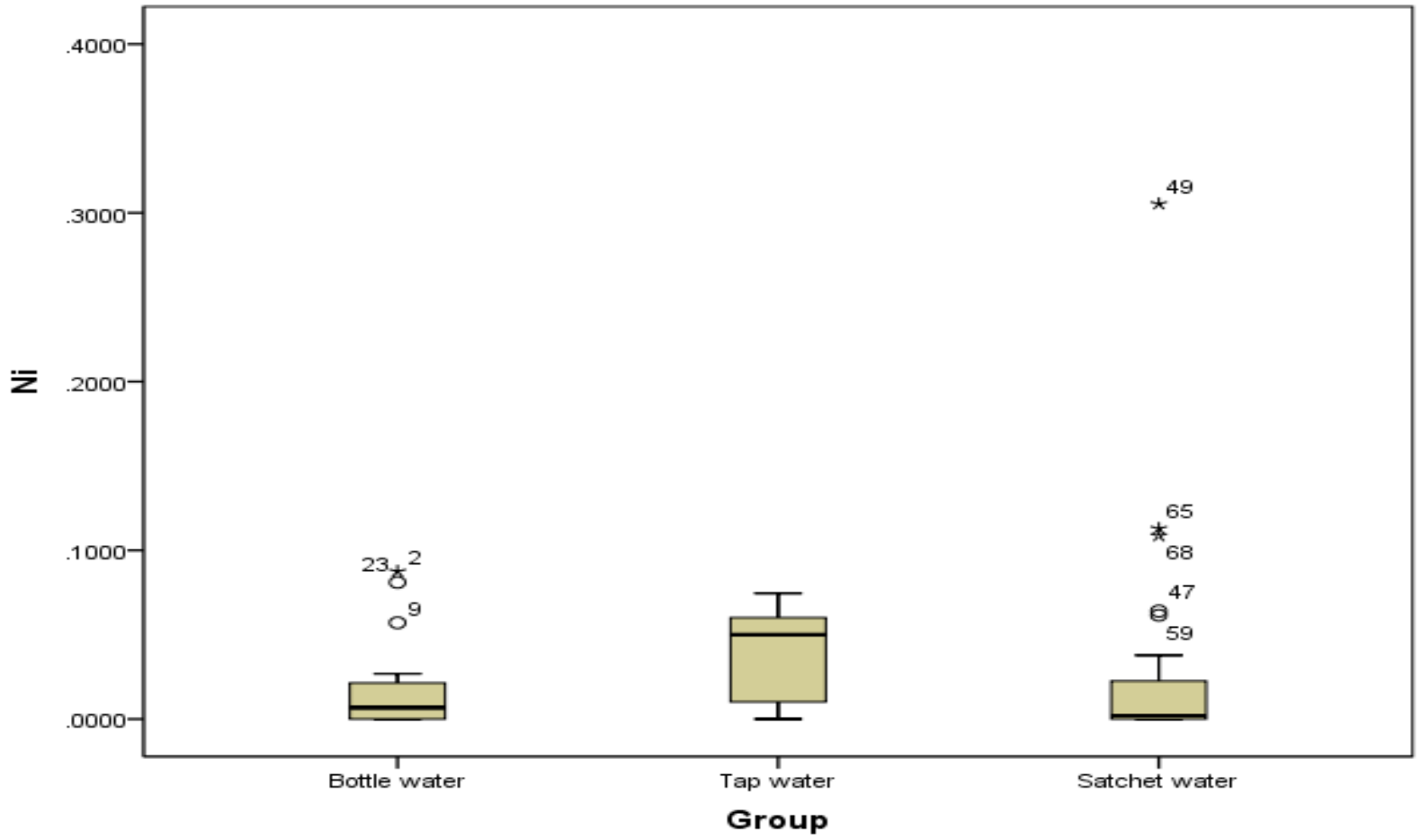

Fig Ilf: Box-plot showing Ni concentrations in packaged (Bottled and Sachet) and tap water samples. Each box includes the 25th and 75th percentiles with the median as thick line; bottom and upper whiskers respectively show the smallest and largest values and the circles indicate the extreme values (outliers)

(llg)

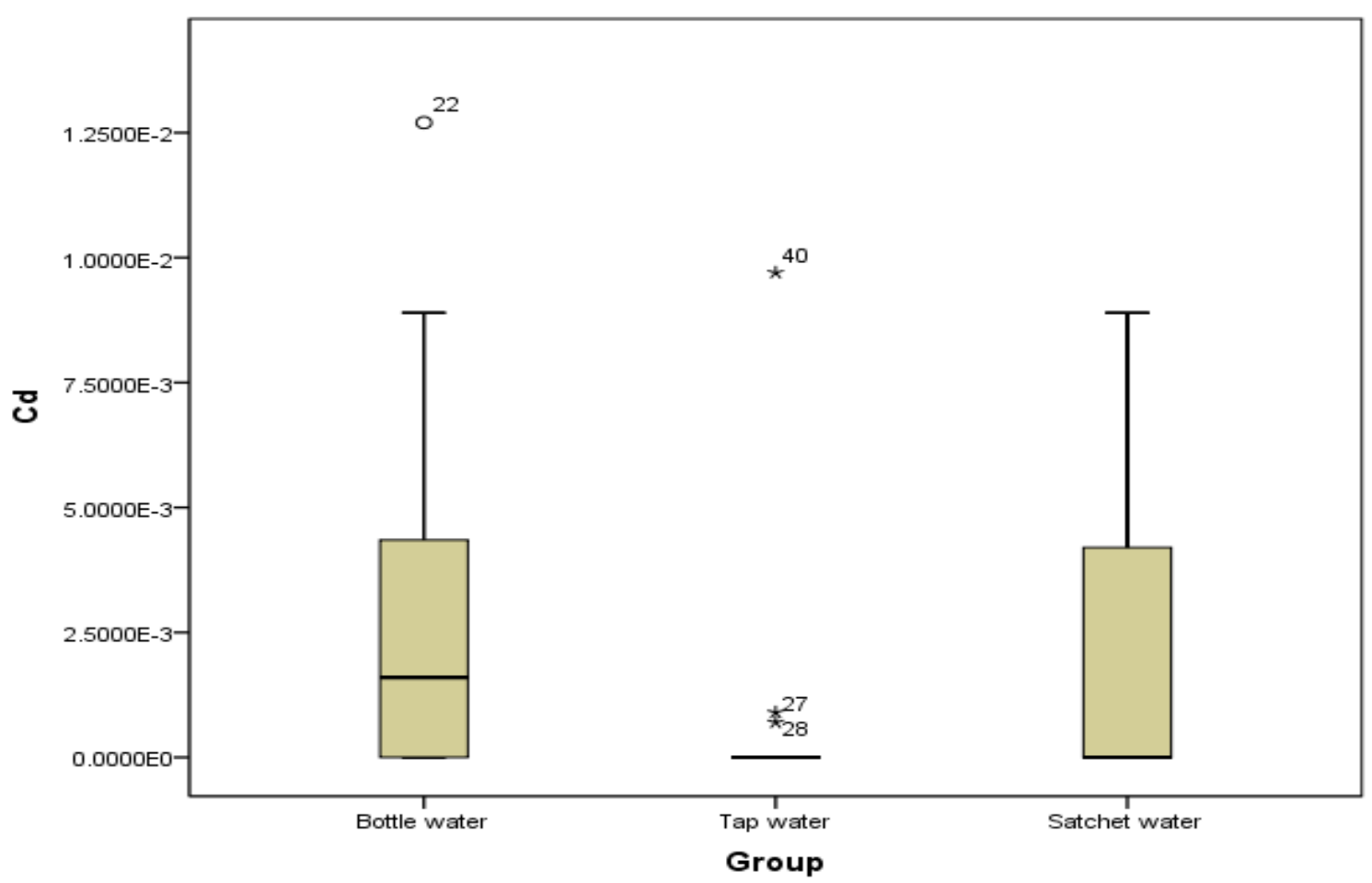

Fig Ilg: Box-plot showing Cd concentrations in packaged (Bottled and Sachet) and tap water samples. Each box includes the 25th and 75th percentiles with the median as thick line; bottom and upper whiskers respectively show the smallest and largest values and the circles indicate the extreme values (outliers) 


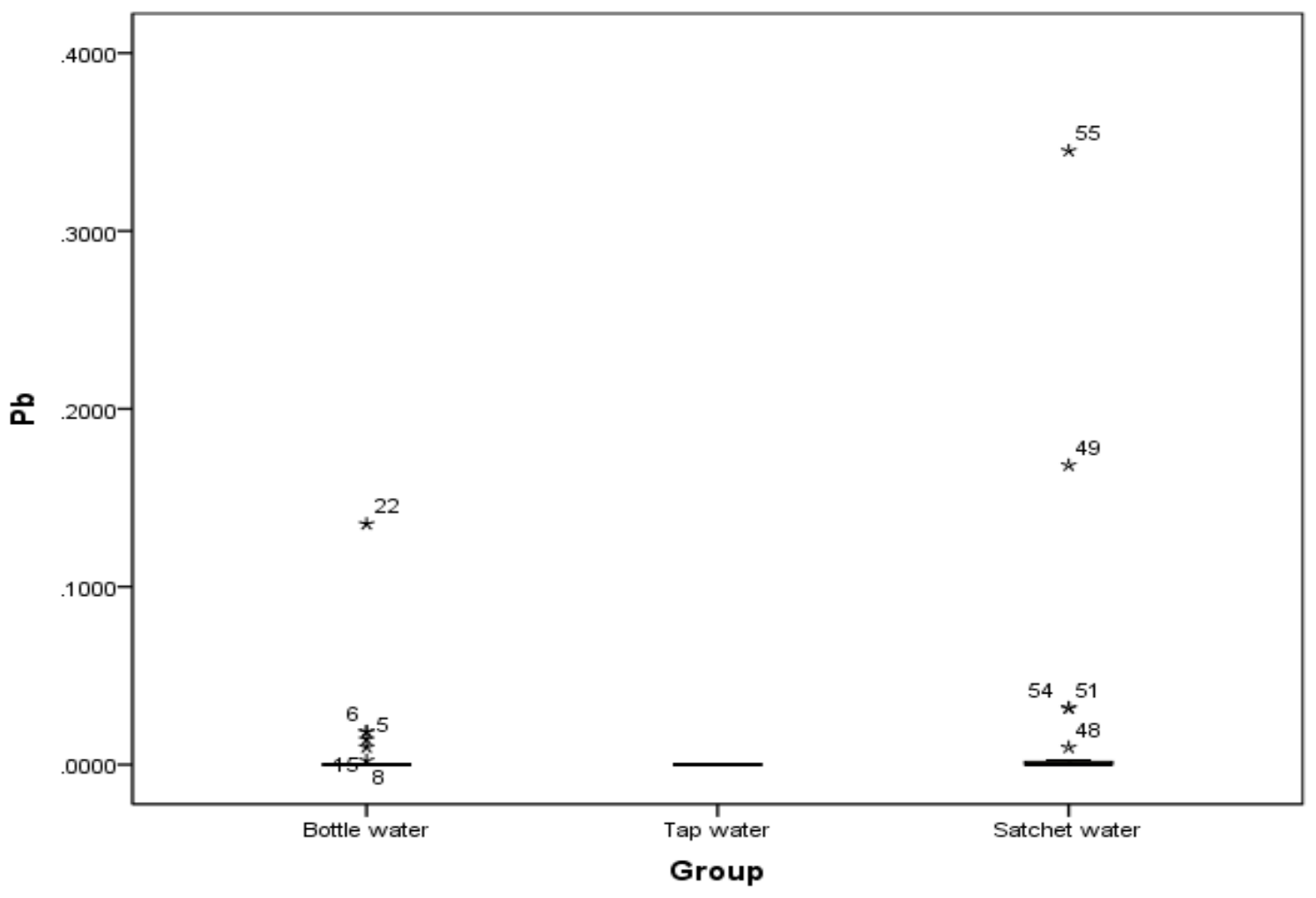

Fig llh: Box-plot showing $\mathrm{Pb}$ concentrations in packaged (Bottled and Sachet) and tap water samples. Each box includes the 25th and 75th percentiles with the median as thick line; bottom and upper whiskers respectively show the smallest and largest values and the circles indicate the extreme values (outliers)

This could be attributed to natural environment from which the water is taken (geological setting, climate, topography, etc.), source water composition and type of treatments applied during their production. Additional changes in the water chemistry may also occur during storage and transportation, especially when bottles and nylon become exposed to direct sunlight [28].

The chemical compositions $\left(\mathrm{Cl}^{-}, \mathrm{NO}_{3}{ }^{-}, \mathrm{SO}_{4}{ }^{2-}, \mathrm{Fe}, \mathrm{Zn}\right.$, $\mathrm{Mn}, \mathrm{Ni}, \mathrm{Cd}$ and $\mathrm{Pb}$ ) in packaged and tap water samples in this study were compared with the Turkish, Malaysian and Italian studies, as shown in Table IV the concentrations of trace metals such as $\mathrm{Fe}, \mathrm{Zn}, \mathrm{Mn}$, and other heavy metals in the studied packaged samples were higher than values reported by Azlan et al. [29] and G"uler and Alpaslan [30]. A study by Naddeo et al. [31] showed that bottled water in Italy had higher mean concentrations in $\mathrm{Fe}, \mathrm{Mn}, \mathrm{Pb}, \mathrm{Cl}^{-}$and $\mathrm{SO}_{4}{ }^{2-}$ than the studied bottled samples.

The studied tap water samples had lower $\mathrm{Cl}^{-}, \mathrm{SO}_{4}{ }^{2-}$ and heavy metal concentrations compared to Malaysian's and Egypt's tap water samples, except for the concentration of $\mathrm{Ni}$ and $\mathrm{Cd}$.

\subsection{Statistical analysis}

Pearson's correlation coefficients among the contents of different ions are presented in Table $\mathrm{V}$. The $\mathrm{Zn}$ and $\mathrm{Mn}(r=0.35), \mathrm{Fe}$ and $\mathrm{Cd}(r=0.49), \mathrm{Mn}$ and $\mathrm{Pb}(r=$ $0.68)$ pairs are positively correlated with each other significantly at the $99 \%$ confidence level, which may suggest a common source or a similar geochemical behavior for these metals.

The results of the ANOVA showed that no significant differences were observed between the packaged (sachet and bottled) and tap waters for $\mathrm{EC}, \mathrm{TH}, \mathrm{SO}_{4}{ }^{2-}$, $\mathrm{Na}, \mathrm{K}, \mathrm{Fe}, \mathrm{Mn}, \mathrm{Ni}, \mathrm{Cd}$ and $\mathrm{Pb}$. The $\mathrm{Cl}^{-} \mathrm{F}(2,26)=3.78$, $\mathrm{p}=0.036 \mathrm{had}$ concentrations in the sachet $(11.80 \mathrm{mg} /$ L) and bottled (16.45 mg/L) water samples respectively to be 1.21 and 1.76 times higher than in the tap water $(9.35 \mathrm{mg} / \mathrm{L})$. The Tukey post- hoc tests indicated that $\mathrm{Cl}^{-}$concentration in bottled water differed significantly from tap water $(p<0.05)$. The $\mathrm{NO}_{3}{ }^{-}$content $\mathrm{F}(2,26)=$ $3.79, p=0.036$ had concentrations in the sachet $(8.07$ $\mathrm{mg} / \mathrm{L})$ and bottled (8.35 mg/L) water samples respectively to be 2.32 and 2.41 times higher than in the tap water $(3.47 \mathrm{mg} / \mathrm{L})$. The Tukey post- hoc tests indicated that $\mathrm{NO}_{3}{ }^{-}$concentration in tap water differed significantly from sachet water $(p<0.05)$.

The Principal Component Analysis (PCA) of the water quality variables extracts four components with eigenvalue $>1.0$, which account $74.82 \%$ of the total variance in the dataset (Table VI). The Kaiser-MeyerOlkim (KMO) criterium for sampling adequacy $(\mathrm{KMO}=0.439)$. However, the correlation matrix and the Barlett's test of sphericity $\left(X^{2}(107.21) \approx 55 ; p<0.00\right)$, both indicated that correlations between items were sufficiently large for PCA [22]. 
Table IV: Concentrations of chemical parameters in packaged (BW and SW) and tap (TW) water Samples from Lagos, Nigeria and other countries.

\begin{tabular}{|c|c|c|c|c|c|c|c|c|c|}
\hline Parameters & $\begin{array}{l}\mathrm{Fe} \\
\mathrm{mg} / \mathrm{L}\end{array}$ & $\begin{array}{l}\mathrm{Zn} \\
\mathrm{mg} / \mathrm{L}\end{array}$ & $\begin{array}{l}\mathrm{Mn} \\
\mathrm{mg} / \mathrm{L}\end{array}$ & $\begin{array}{l}\mathrm{Ni} \\
\mathrm{mg} / \mathrm{L}\end{array}$ & $\begin{array}{l}\mathrm{Cd} \\
\mathrm{mg} / \mathrm{L}\end{array}$ & $\begin{array}{l}\mathrm{Pb} \\
\mathrm{mg} / \mathrm{L}\end{array}$ & $\begin{array}{l}\mathrm{Cl}^{-} \\
\mathrm{mg} / \mathrm{L}\end{array}$ & $\begin{array}{l}\mathrm{NO}_{3}^{-} \\
\mathrm{mg} / \mathrm{L}\end{array}$ & $\begin{array}{l}\mathrm{SO}_{4}^{2-} \\
\mathrm{mg} / \mathrm{L}\end{array}$ \\
\hline $\begin{array}{l}\text { Country } \\
\text { aPresent }\end{array}$ & & & & & & & & & \\
\hline $\begin{array}{l}\text { study(SW) } \\
\text { apresent }\end{array}$ & 0.02 & 0.05 & 0.04 & 0.03 & 0.002 & 0.02 & 11.8 & 8.07 & 6.94 \\
\hline study(BW) & 0.02 & 0.02 & 0.009 & 0.02 & 0.003 & 0.008 & 16.5 & 8.35 & 5.7 \\
\hline bMalaysia & 0.011 & 0.0048 & 0.031 & 0.0015 & 0.00036 & 0.00026 & 34.46 & 1.16 & 9.35 \\
\hline cTurkey & 0.0023 & 0.01 & 0.00009 & 0.00005 & 0.000037 & 0.000021 & 3.23 & 3.01 & 6.46 \\
\hline dItaly & 0.182 & 0.045 & 0.627 & 0 & 0.000038 & 0.35 & 96.95 & 5.51 & 113.82 \\
\hline $\begin{array}{l}\text { aPresent } \\
\text { study(TW) }\end{array}$ & 0.003 & 0.009 & 0.02 & 0.03 & 0.001 & nd & 9.35 & 3.47 & 10.8 \\
\hline bMalaysia & 0.058 & 0.034 & 0.025 & 0.00009 & 0.000041 & 0.000028 & 20.2 & 1.39 & 10.2 \\
\hline eEgypt & 0.073 & 0.083 & 0.0052 & 0.0025 & 0.00004 & 0.00018 & 45.3 & 0.03 & 69.1 \\
\hline
\end{tabular}

Sources: aPresent study; ${ }^{b}$ Azlan et al. [29]; ' $G "$ uler and Alpaslan [30]; 'Naddeo et al. [31]; ' $S a l e h$ et al. [5]. 
Table V: Pearson's correlation coefficients between metals in drinking water samples

\begin{tabular}{lllllllll}
\hline & $\mathrm{Na}$ & $\mathrm{K}$ & $\mathrm{Zn}$ & $\mathrm{Mn}$ & $\mathrm{Fe}$ & $\mathrm{Ni}$ & $\mathrm{Cd}$ & $\mathrm{Pb}$ \\
\hline $\mathrm{Na}$ & 1 & 0.082 & -0.055 & -0.095 & -0.063 & -0.081 & -0.146 & -0.142 \\
$\mathrm{~K}$ & 0.082 & 1 & -0.05 & -0.09 & -0.079 & -0.146 & -0.121 & -0.106 \\
$\mathrm{Zn}$ & -0.055 & -0.05 & 1 & $0.353^{* *}$ & -0.027 & -0.17 & -0.146 & -0.077 \\
$\mathrm{Mn}$ & -0.095 & -0.09 & $0.353^{* *}$ & 1 & -0.001 & -0.09 & -0.001 & $0.678^{* *}$ \\
$\mathrm{Fe}$ & -0.063 & -0.079 & -0.027 & -0.001 & 1 & 0.044 & $492^{* *}$ & $0.249^{*}$ \\
$\mathrm{Ni}$ & -0.081 & -0.146 & -0.17 & -0.09 & 0.044 & 1 & -0.138 & 0.226 \\
$\mathrm{Cd}$ & -0.146 & -0.121 & 0.146 & -0.001 & $0.492^{* *}$ & -0.138 & 1 & 0.194 \\
$\mathrm{~Pb}$ & -0.142 & -0.106 & -0.077 & $0.678^{* *}$ & $0.249^{*}$ & 0.226 & 0.194 & 1 \\
\hline
\end{tabular}

${ }^{*}$ Correlation is significant at the 0.05 level (2-tailed); ${ }^{* *}$ Correlation is significant at the 0.01 level (2-tailed).

Table VI: Total variance explained and component matrix for parameters

\begin{tabular}{lllll}
\hline Variable & Factor & & \\
& component 1 & component 2 & component 3 & component 4 \\
\hline
\end{tabular}

\begin{tabular}{|c|c|c|c|c|}
\hline \multicolumn{3}{|l|}{ EC } & \multicolumn{2}{|l|}{0.831} \\
\hline TH & & & 0.788 & \\
\hline $\mathrm{Cl}^{-}$ & 0.865 & & & \\
\hline $\mathrm{NO}_{3}^{-}$ & 0.845 & & & \\
\hline $\mathrm{Na}$ & 0.724 & & & \\
\hline K & 0.574 & & & \\
\hline $\mathrm{Zn}$ & & & & 0.965 \\
\hline $\mathrm{Ni}$ & & 0.884 & & \\
\hline $\mathrm{Pb}$ & & 0.936 & & \\
\hline Eigenvalue & 2.357 & 1.828 & 1.527 & 1.022 \\
\hline Explained variance (\%) & 26.185 & 20.313 & 16.968 & 11.355 \\
\hline Cumulative $\%$ of variance & 26.185 & 46.498 & 63.466 & 74.821 \\
\hline
\end{tabular}

The first Principal Component (PC1) accounted for $26.85 \%$ of the total variance and contains most of the information on the monovalent ions $\mathrm{Cl}^{-}, \mathrm{NO}_{3}{ }^{-}, \mathrm{K}$ and $\mathrm{Na}$ (with loadings $0.86,0.84,0.57$ and 0.72 respectively). The first principal component (PC1) can therefore be considered as a measure for the water saltiness [32]. The second Principal Component (PC2) explained $20.31 \%$ of the total variance and is characterized by positive loadings in $\mathrm{Mn}$ and $\mathrm{Pb}$ (with loadings 0.88 and 0.94 respectively). This principal component can be considered as a measure of the anthropogenic inputs. The third Principal Component (PC3) explained 16.97 $\%$ of the total variance and contains information on the
EC and TH (with loading 0.82 and 0.81 respectively) and mostly contains information on the water hardness. The fourth Principal Component (PC4) was mainly related to $\mathrm{Zn}$ which could be due to mineralization.

Hierarchical Cluster Analysis (HCA) using ward's method was performed to detect similarity group among the water samples (bottled, sachet and tap waters). The resulting dendrogram (Fig. III) has four clusters based on a similarity of nine parameters. The first cluster was predominant and characterized by 


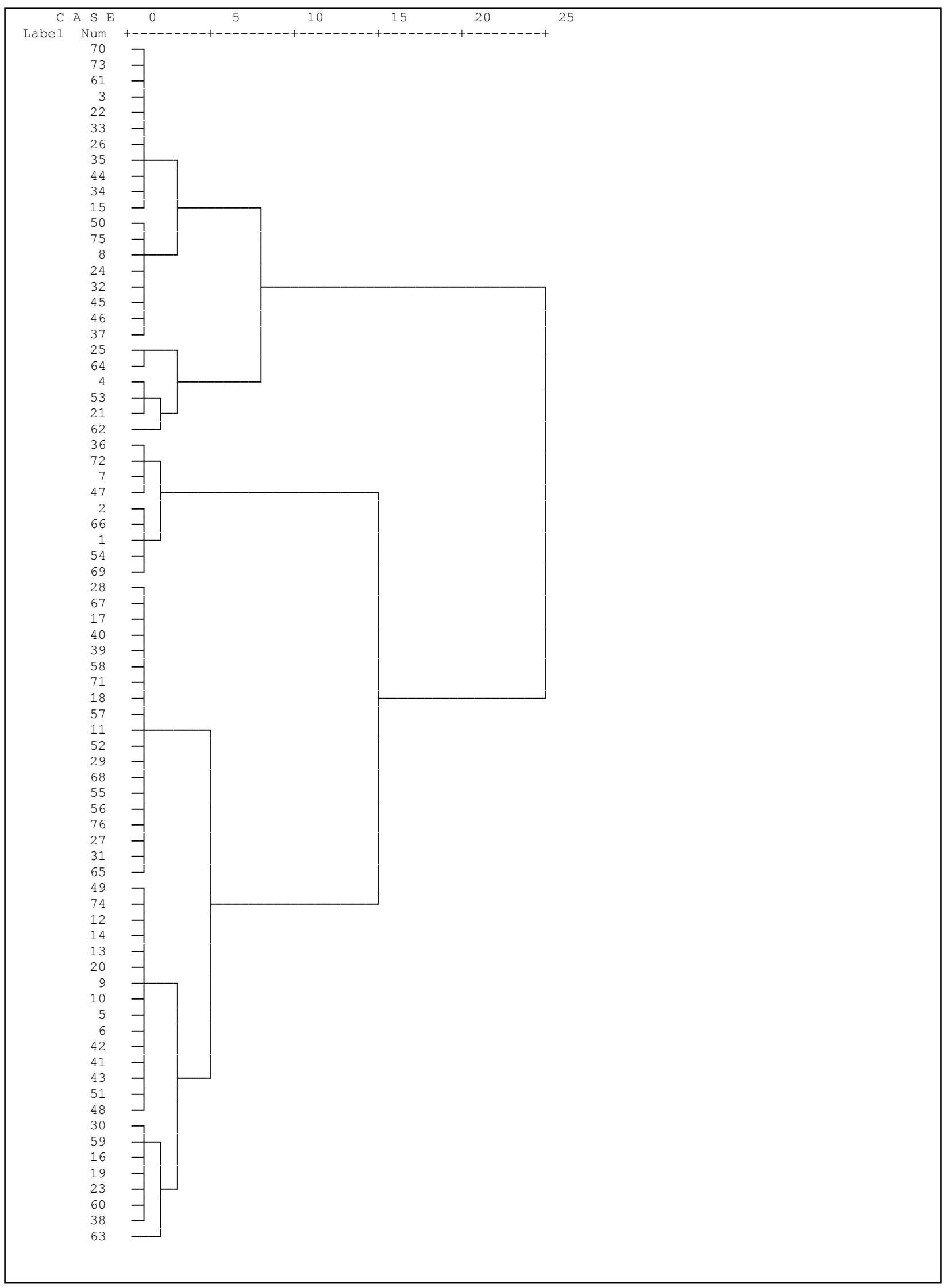

Fig. III: Heierarchical Dendrogram using Ward's method 
high $\mathrm{Cl}^{-}, \mathrm{NO}_{3}^{-}, \mathrm{Na}$ and $\mathrm{K}$. The second group represents the water brands $\mathrm{Mn}$ and $\mathrm{Pb}$. The third cluster was essentially high $\mathrm{EC}$ and $\mathrm{TH}$ while the fourth group had high $\mathrm{Zn}$. The results of $\mathrm{HCA}$ coincide with those obtained from PCA.

In Table VII the canonical discriminant function coefficients for the different variables are presented for the performed discriminant analysis. The eigenvalues of the discriminant functions are presented as well. Fig. IV presented the canonical discriminant functions for the different water types.

It can be seen that there are two discriminant functions. The Wilk's Lambda is statistically significant for one of the functions at a significance level $p<0.05$. The first discriminant function (DF1) accounted for $70.2 \%$. The eigenvalue (2.09) and canonical correlation ( $\mathrm{rc}=0.823$ ) values with small Lambda (0.171), a chi-square of 38.833 and $p=0.003$. The second discriminant function (DF2) accounted for 29.8 $\%$. The eigenvalue $(0.890)$ and canonical correlation ( $\mathrm{rc}=0.686)$ values with a large Lambda (0.529), a chisquare of 14.00 and $p=0.082$. Thus only one of the two functions explains the variation. The variables $\mathrm{NO}_{3}{ }^{-}$and $\mathrm{Cl}^{-}$are strongly correlated with DF1, confirming previous findings: $\mathrm{NO}_{3}{ }^{-}$and $\mathrm{Cl}^{-}$are the main discriminating factors between the packaged and tap water. 'Bottled water' (i.e group 1) has the highest mean, while 'tap water' (i.e group 3) has the lowest as shown in Fig. IV. In total 25 out of 29 water types were classified correctly. This corresponds with $86.2 \%$ of the water types. This indicates that a considerable amount of discriminatory information was accounted for by the discriminatory variables.

Table VII: Canonical discriminant function coefficient $(\beta i)$ for the different original variables and eigenvalues of the discriminant functions

\begin{tabular}{cll}
\hline \multicolumn{3}{c}{ Variable Function } \\
& 1 & 2 \\
\hline $\mathrm{EC}$ & -0.321 & -0.141 \\
$\mathrm{TH}$ & -0.057 & -0.11 \\
$\mathrm{Cl}^{-}$ & 1.037 & -0.714 \\
$\mathrm{NO}_{3}^{-}$ & 0.564 & 0.42 \\
$\mathrm{Na}$ & -0.536 & -0.317 \\
$\mathrm{~K}$ & -0.753 & 0.659 \\
$\mathrm{Zn}$ & 0.89 & 0.27 \\
$\mathrm{Mn}$ & -1.015 & 0.84 \\
$\mathrm{~Pb}$ & 1.15 & -0.238 \\
$\mathrm{Eigenvalue}$ & 2.092 & 0.89 \\
\% of Explained variance & 70.2 & 29.8 \\
\hline
\end{tabular}

\section{CONCLUSION}

In this study, the drinking quality of tap and packaged water in selected part of Lagos was investigated. In terms of the drinking quality, tap water is closely matching the bottled water. Therefore, tap water drinking quality should not pose any serious public threat. The results show that the concentrations of water constituents in both tap and packaged waters were within or below the threshold levels set for drinking water by the national and international standard. The only concern was the nitrate $\left(\mathrm{NO}_{3}^{-}\right)$ content, as $11 \%$ and $20 \%$ of bottled and sachet water respectively exceeded the USEPA standard of $10 \mathrm{mg}$ $\mathrm{L}^{-1}$.

The application of different multivariate statistical techniques, such as Correlation Analysis (CA), Principal Component Analysis (PCA), Hierarchical Cluster Analysis (HCA) and discriminant analysis were used to provide information on the composition of water and characterized them according to their sources. PCA identified four factors, which carry $\sim 75$ $\%$ of the total variance of the dataset. HCA classified the water samples into four different groups based on the similarity of water quality characteristics. Analysis of variance concluded that there exists a significant difference in $\mathrm{NO}_{3}{ }^{-}$and $\mathrm{Cl}^{-}$concentrations between the packaged and tap water. The discriminant analysis revealed $\mathrm{NO}_{3}{ }^{-}$and $\mathrm{Cl}^{-}$ions as the main discriminating factor.

One main recommendation of this study is that water supply and public health authorities should address the high level of chemicals present in an individual water supply that may pose a public health risk from longterm exposure. To protect human health, proper drinking water monitoring systems should be implemented to ensure that the physiochemical parameters of drinking water match acceptable national standards. A moderate use of packaged waters is also recommended. A reduced consume of bottled and sachet waters would also help to decrease the impact of plastic and nylon packaging on the environment, especially in Nigeria where recycling of plastic materials is very low at present.

\section{ACKNOWLEDGEMENTS}

The authors greatly acknowledge Prof. P.O. Okebukola the founder of STERG for his contribution on the use of statistical analysis to interpret the data.

\section{CONFLICT OF INTEREST STATEMENT}

The authors declare that there are no conflicts of interest.

\section{AUTHORS' CONTRIBUTIONS}

Author 1' designed the experiment, and interprets the data using statistical analysis.

Authors 2 and 3 contributed to sampling, literature searches and references.

All authors read and approved the final manuscript. 


\section{Canonical Discriminant Functions}

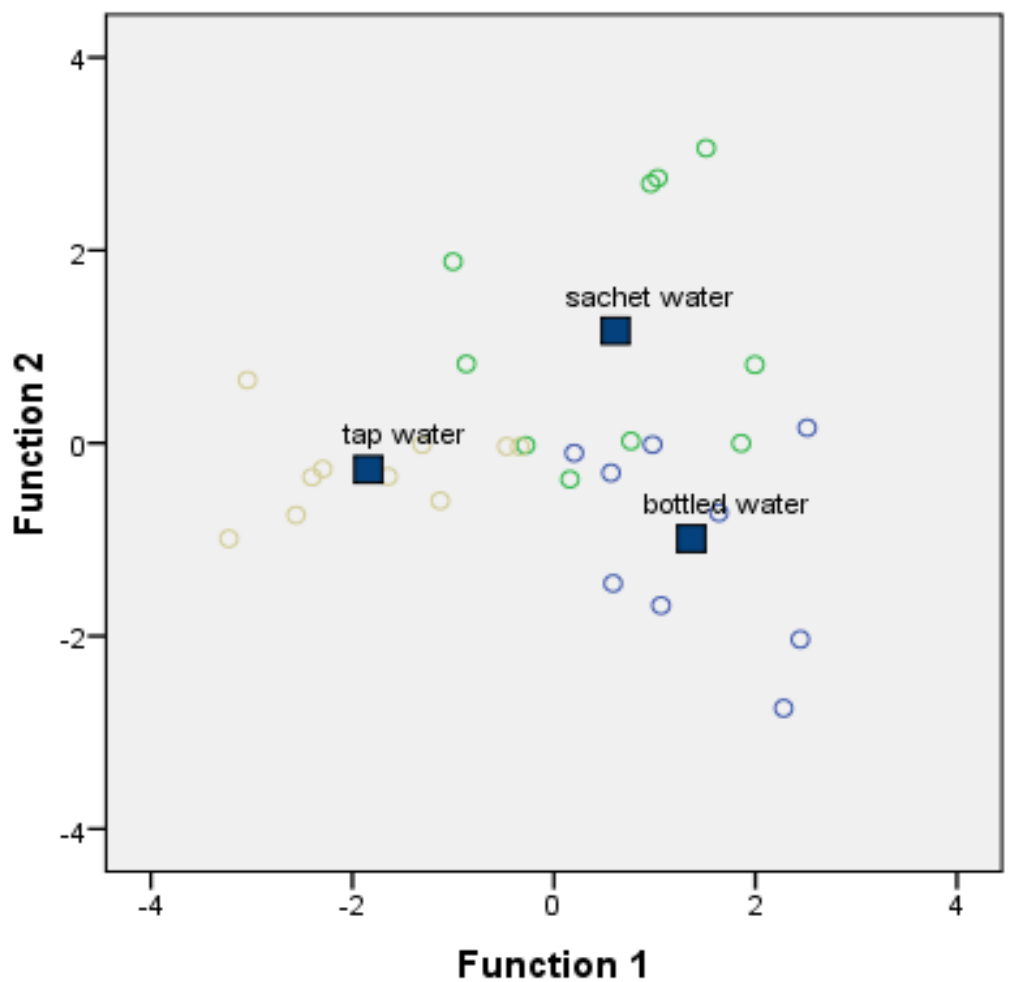

Type

bottled water

sachet water

tap water

Group Centroid

Function 1

Fig. IV: The canonical discriminant functions for the different water types: bottled water (o), sachet water (o) and tap water (o).

\section{REFERENCES}

1. Adeniyi A, Yusuf K, Okedeyi O, Sowemimo M. Classification and Health Risk Assessment for Borehole Water Contaminated by Metals in Selected Households in Southwest Nigeria. J. of Water Resource and Protection. 2016;(8):459-471.

2. Chanpiwat $P$, Lee B, Kim K, Sthiannopkao $S$. Human Health Risk Assessment for Ingestion Exposure to Groundwater Contaminated by Naturally Occurring Mixtures of Toxic Heavy Metals in the Lao PDR. Environ. Monit. and Assess. 2014;186:49054923.

3. Alsulaili A, Al-Harbi M, Al-Tawari K. Physical and chemical characteristics of drinking water quality in Kuwait: tap vs. bottled water. J. of Engg. Research. 2015;3(1):25-50.

4. Ikem A, Odueyungbo S, Egiebor NO, Nyavor K. Chemical quality of bottled waters from three cities in eastern Alabama. Sci. Total. Environ. 2002;285:165175.
5. Saleh MA, Ewane E, Jones J, Wilson BL. Chemical evaluation of commercial bottled drinking water from Egypt. Journal of Food Composition and Analysis 2001;14:127-152.

6. Parag $\mathrm{Y}$, Roberts J. A battle against the bottles: building, claiming, and regaining tap-water trustworthiness. Society and Natural Resources. 2009;22:625-636.

7. Chen $B$, Westerhoff $P$. Predicting disinfection byproduct formation potential in water. Water Res. 2010;44:3755-3762.

8. Lagos Water Corporation. 2011. "LWC TARGETS 733 MILLIONS DAILY BY 2020",

http://www.lagoswater.org/news. php?page $=45$.

9. Cidu R, Frau F, Tore P. Drinking water quality: Comparing inorganic components in bottled water and Italian tap water. J. Food Comp. Anal. 2011;24:184193.

10. Dario Di Giuseppe. Comparison of the Mineral Element Content of Public Drinking Fountains and 
Bottled Water: A Case Study of Ferrara City. Geosciences.2017;7:76;doi:10.3390/geosciences7030 076 http://www.mdpi.com/2076-3263/7/3/76.

11. Ajayi AA, Sridhar MKC, Adekunle LV, Oluwande PA. Quality of Packaged Waters Sold in Ibadan, Nigeria. African J. of Biomedical Res. 2008;11:251258.

12. Opatunji O, Obhiambo F. Consumption practices and user perception of an emerging alternative drinking water option (sachet water) in Ibadan, Nigeria. 35th WEDC International Conference; Loughborough, UK. 2011.

13. American Public Health Association (APHA). Standard Methods for the examination of water and wastewater, APHA, AWWA, and WPCE, 20th edn. Byrd Progress, Springfield. 1998.

14. Astel A, Tsakovski S, Barbieri $P$, Simeonov V. Comparison of self-organizing maps classification approach with cluster and principal components analysis for large environmental data sets. Water Res. 2007;41(19):4566-4578.

15. Astel A, Tsakovski S, Simeonov V, Reisenhofer E, Piselli S, Barbieri P. Multivariate classification and modeling in surface water pollution estimation. Anal. Bioanal. Chem. 2008;390(5):1283-1292.

16. Brereton RG. Chemometrics, data analysis for the laboratory and chemical plant, Wiley, UK, 2003.

17. Dinelli E, Lima A, De Vivo B, Albanese S, Cicchella D, Valera P. Hydrogeochemical analysis on Italian bottled mineral waters: Effects of geology. J. Geochem. Explor. 2010;107: 317-335.

18. Mencio A, Mas-Pla J. Assessment by multivariate analysis of groundwater surface water interactions in urbanized Mediterranean streams. J. Hydrol. 2008;352:355-366.

19. Simeonova $\mathrm{P}$, Simeonov V. Chemometrics to evaluate the quality of water sources for human consumption. Microchimica. Acta. 2007;156(3-4):315320.

20. Kaiser HF. The application of electronic computers to factor analysis. Educational and Psychological Measurement. 1960;20:141-151.

21. Güler C, Thyne GD, McCray JE, Turner AK. Evaluation of graphical and multivariate statistical methods for classification of water chemistry data. Hydrogeol. J. 2002;10(4):455-474.
22. Hair JF, Anderson RE, Tatham RL, Black WC. Multivariate Data Analysis 5th ed. Prentice-Hall. New Jersey USA. 1998.

23. Smetti EM, Thanasoulias NC, Lytras ES, Tzoumerkas PC, Golfinopoulos SK. Treated water quality assurance and description of distribution networks by multivariate chemometrics. Water Res. 2009;43:4676-4684.

24. Nigerian Standard for Drinking Water Quality. The Nigerian Industrial Standards for Potable Water NIS 554. 2007.

25. United States Environmental Protection Agency (USEPA). Exposure Factors Handbook 2011th ed. United States Environmental Protection Agency, Washington DC. 2011.

26. World Health Organization (WHO). Guidelines for drinking water quality 4th ed. Geneva, ISBN: 978924 154815 1. 2011.

27. Crittenden JC, Trussell R, Hand DW, Howe KJ, Tchobanoglous G. Water Treatment: Principles and Design. 2nd ed. John Wiley, Hoboken, NJ. 2005.

28. Ghrefat H. Classification and Evaluation of Commercial Bottled Drinking Waters in Saudi Arabia. Research J. of Environ. and Earth Sciences 2013;5:210-218.

29. Azlan $A$, Khoo HE, Idris MA, Ismail $A$, azman MR. Evaluation of minerals content of drinking water in Malaysia. The Scientific World J. 2011;2012:1-10.

30. Güler C, Alpaslan M. Mineral content of 70 bottled water brands sold on the Turkish market: Assessment of their compliance with current regulations. J. Food Comp. and Anal. 2009;22:728-737.

31. Naddeo V, Zarra T, Belgiorno V. "A comparative approach to the variation of natural elements in Italian bottled waters according to the national and international standard limits. Journal of Food Composition and Analysis. 2008; 21(6):505-514.

32. Versari A, Parpinello GP, Galassi S. Chemometric survey of Italian bottled mineral waters by means of their labelled physico-chemical and chemical composition. J. of Food Comp. and Anal. 2001;15: 251-264. 